\title{
Problems of and solutions for the study of immigrant integration
}

Rinus Penninx

Correspondence:

M.J.A.Penninx@uva.nl

University of Amsterdam,

Amsterdam, The Netherlands

\begin{abstract}
In his contribution, Willem Schinkel makes critical observations on the concept of immigrant integration and its use in Europe, specifically in the Netherlands. Three of these are agreeable: there is a lot of fuzziness around the concept; there is clearly selectivity and normativity in its use in political rhetoric and in research; there is also a strong influence of politics and policy on what is researched and how. However, Schinkel's diagnosis of why these shortcomings exist and whose shortcomings these are, is erratic. Firstly, he does not recognize that the concept of integration has fundamental different functions in research and in policy. That makes his diagnosis of why the integration concept in research is problematic misleading. Secondly, Schinkel's analysis focuses on the assumed function of research: "..it plays a crucial role in the problematization of migrant others" and "it is part of the contingent way in which 'immigrant integration' sustains a classed and raced form of dominance that is less precisely called 'native' or even 'nativist' than 'white'." Such sweeping interpretations lead Schinkel to plea "for a social science against immigrant integration policy", whatever that would mean. The author of this article offers an alternative solution to problems of research that Schinkel signalizes. It includes three main elements: a) a broad, heuristic, scientific definition of the process of integration that studies the (outcomes of) interaction between newcomers and the receiving society at three levels (individual, collective and institutional), taking into account three dimensions of that process: the juridical/legal, the socioeconomic and the cultural/religious dimension. Such a definition is (and should be) independent of any policy concept of integration. b) studying integration policies as fundamentally different from the analysis of the process of integration; the former should be studied as - by definition normative, politics driven - efforts to steer integration processes. c) researchers should be aware of the consequences of policy-researchrelations (particularly funding) and assure their scientific independence.
\end{abstract}

Keywords: Integration of immigrants, Conceptualization of Integration, Integration policies

\section{Problematic concepts, policies and research}

In his contribution, entitled "Against 'immigrant integration': For an end to neocolonial knowledge production", Willem Schinkel makes a number of sharp, critical observations on the concept of immigrant integration and its use in Europe in recent times, specifically in the Netherlands. At first sight, one can agree with a number of his critical remarks.

(c) The Author(s). 2019, corrected publication 2019. Open Access This article is distributed under the terms of the Creative Commons Attribution 4.0 International License (http://creativecommons.org/licenses/by/4.0/), which permits unrestricted use, distribution, and reproduction in any medium, provided you give appropriate credit to the original author(s) and the source, provide a link to the Creative Commons license, and indicate if changes were made. 
1. Yes, there has been and still is a lot of political discourse on (failed) multiculturalism and on (failed) integration that uses these concepts in a very specific way. When government leaders such as Merkel, Sarkozy and Cameron distance themselves in seemingly concerted action from multiculturalism, they do this against a very different background of national philosophies and practices of integration policies in their respective countries (in which multiculturalism often had no place at all). Such references to "failed multiculturalism" and "failed integration" should be seen and studied as efforts to (re-)frame immigrants' past and future place in European societies. This reframing takes place in a context of renascent nationalism and politicization of migration and integration issues. The concepts used in such political statements do not have any relation with scientific concepts of multiculturalism as they were developed in the Canadian political science literature (Kymlicka, 2001) or the concept of integration as it was developed in the European social science literature (see below).

2. Yes, one can agree with the observation that in a substantial part of research, particularly that part that is commissioned by politics and policy institutions, one can find the reflection of a neo-liberal framing of what immigrant integration should be and who is responsible for the outcomes of the integration process. That way of looking at integration pays one-sidedly attention to the measurement of integration on the individual level, to the (lack of) efforts of individuals to adapt to society, and to cultural and/or religious characteristics of newcomers that supposedly hamper their integration. Such a measurement of the integration of individual newcomers does indeed leave out factors on the collective and institutional level of the society that determines the integration opportunities of newcomers by including or excluding them through institutional arrangements, by actions of organized collectivities or by individuals (or any combination of these three).

3. Yes, the standards (or reference group) against which the position of those who are defined as target groups of integration policies are measured is often problematic. Measuring a specific category of newcomers against an average of the autochthonous population is not teaching us a lot about the integration process of newcomers, if we exclude an analysis of how specific characteristics of newcomers are accepted (or not) by society, i.e. the inclusion or exclusion on the institutional, organizational and individual level. A comparison of the position of the Turkish and the Japanese immigrant group in Amsterdam makes that immediately visible. The socio-economic characteristics (and the acceptance by institutions, organizations and individuals in Dutch society) are fundamentally different for the two groups, resulting in a different process of integration and different outcomes in positions.

\section{Schinkel's assessment of the state-of-the-art of integration research}

Schinkel claims that he bases his analysis on research on immigrant integration in Western Europe, specifically The Netherlands; research that he critiques for 'for bad (or lacking) conceptual work, specifically also in regard to the notion of "society"' (p.1). And yes, Schinkel refers to studies, particularly those that "measure" integration, that can be labeled as poorly conceptualized or following policy concepts. 
But that cannot seriously be taken as the general State-of-the-Art of the scientific study of what happened to immigrants in Europe and the Netherlands after their arrival. In his contribution no reference is made to scientists that have done important work to develop comprehensive analytical concepts for the study of the settlement of newcomers in a society, such as Bommes (2012), Esser (1980), Heckmann (1981, 2015), Heckmann and Schnapper (2003) and Hoffmann-Nowotny (1973), to name just a few. The notion of society is central in all these approaches. Esser (2004, p. 46) defines integration as 'the inclusion [of individual actors] in already existing social systems'. For Heckmann (2006, p. 18), integration is 'a generations lasting process of inclusion and acceptance of migrants in the core institutions, relations and statuses of the receiving society'. According to Bommes (2012, p. 113), 'the problem of migrant assimilation refers to no more (and no less) than the conditions under which they succeed or fail to fulfil the conditions of participation in social systems'. In the Dutch case, Penninx (1988, 2005), Penninx and Garcés-Mascareñas (2016) and Van Amersfoort (1982) have worked in the same vain on the analytical study of the process of settlement and integration (the first three studies asking the crucial question whether and under what circumstances such a process would lead to "minority formation").

Schinkel also does not seem to be aware of conceptual work on the study of integration policies (as efforts of governments to steer integration processes in a direction that the receiving society wants). In Europe, a tradition of studying integration policies in a comprehensive way started with the classical study of Hammar (1985) and had also prominent proponents in the Netherlands, like Entzinger (1984) and recently Scholten (2011). All of these studies have escaped Schinkel's attention. The picture that Schinkel draws is a list of weaknesses of research (and often policy debates) that he presents as a state-of-the-art of research and on which he bases his conclusion "for a social science against immigrant integration policy".

\section{Conflation of the study of (the process of) integration and of integration policies}

In discussing conceptualizations of integration (and multiculturalism in the beginning of his article), Schinkel switches continuously between the use of concepts in political debates and policy framing on the one hand, and the use of concepts in research on the other. As if these were the same. The concept of integration, however, has a different function and meaning in research and in policymaking. In scientific research a comprehensive, open (meaning non-normative), analytical concept is needed to study the process of settlement and integration (I will elaborate on this below). The essence of policies, however, is the intention to guide and steer processes in society, in our case, integration processes of immigrants. Integration policies are part of a normative political process in which the issue of integration is formulated as a problem, the problem is given a normative framing, and concrete policy measures are designed and implemented to achieve a desired outcome. The study of policies is thus fundamentally different from the study of integration processes. When studying integration policies, the first question to be analysed is how different political and social actors perceive and frame immigrant integration. A frame is a reconstruction of the problem and a definition of a policy issue, including the underlying assumptions of the problem's causes 
and possible remedies. Studying policies means thus looking at how the problem is actually defined and explained and what is proposed that should be done about it.

Mixing up the use of integration concepts in research and in policies, and attributing the consequences of both to research leads Schinkel to generalizing conclusions: research "..plays a crucial role in the problematization of migrant others" and "it is part of the contingent way in which 'immigrant integration' sustains a classed and raced form of dominance that is less precisely called 'native' or even 'nativist' than 'white'." Such interpretations lead the author to conclude "for a social science against immigrant integration policy".

\section{Policy-research relations and its consequences}

The conclusions above summarize Schinkel's ideas and interpretations of how research and policy relate to each other: research (in particular that of "privileged white researchers"1) sustains (white, higher class) power that suppresses lower classes and non-whites in general, and migrants in particular through integration policies. Are these sustainable and meaningful statements on research-policy relations?

To be sure, research-policy relations are often problematic. But they deserve a better analysis than Schinkel's one as a compass for researchers how to handle these relations. Interestingly, there is quite a literature on this both on the European level (summarized in Boswell, 2009; Favell, 2003; Scholten, Entzinger, Penninx, \& Verbeek, 2015) and in the Dutch case (Entzinger, 1986; Penninx, 1988; Scholten, 2011; Van Amersfoort, 1983; Verbeek, Entzinger, \& Scholten, 2015). That literature analyses the different components of the relation: is knowledge production influenced and steered by policy and how? Is policymaking influenced by research, how and when? What role do dialogue structures play in both directions? The general conclusion from this research is that there are historically many different forms of dialogue structures, and that both deep influences from research to policy and vice versa can be demonstrated. It is also clear that the more the issue of integration is politicized, the stronger the dominance of policy frames over research concepts (through funding of specific issues, etc.) on the one hand, and the weaker the influence of research on policy on the other (more symbolic than instrumental use of research). In such a politicized situation, the pressure on research to use and communicate in policy concepts and frames (rather than scientific ones) is stronger. Also, research and data collection by in-house departments of policy institutions increases as opposed to research of academic institutes.

Yes, I think it is fair to say that in the present politicized situation, researchers should be more aware of what their possible contribution to or function for policymaking is; and that they should be careful in the choice and use of their (own, scientific) concepts. That is the case for academic (internally funded) research, but particularly for research done on demand and funded by politics and policy institutions (Penninx, 2017). But there is no reason to advise "for a science against immigrant integration policy", as long as we have and use our independent, non-normative analytical concepts. In the next paragraph I will briefly outline the analytical concept of the process of integration as we (Penninx \& Garcés-Mascareñas, 2016) have formulated it recently, building on the work that we mentioned above. That analytical concept can also be used to situate specific research projects in the comprehensive study of integration processes (and indicate what part it covers and which parts it does not cover). 


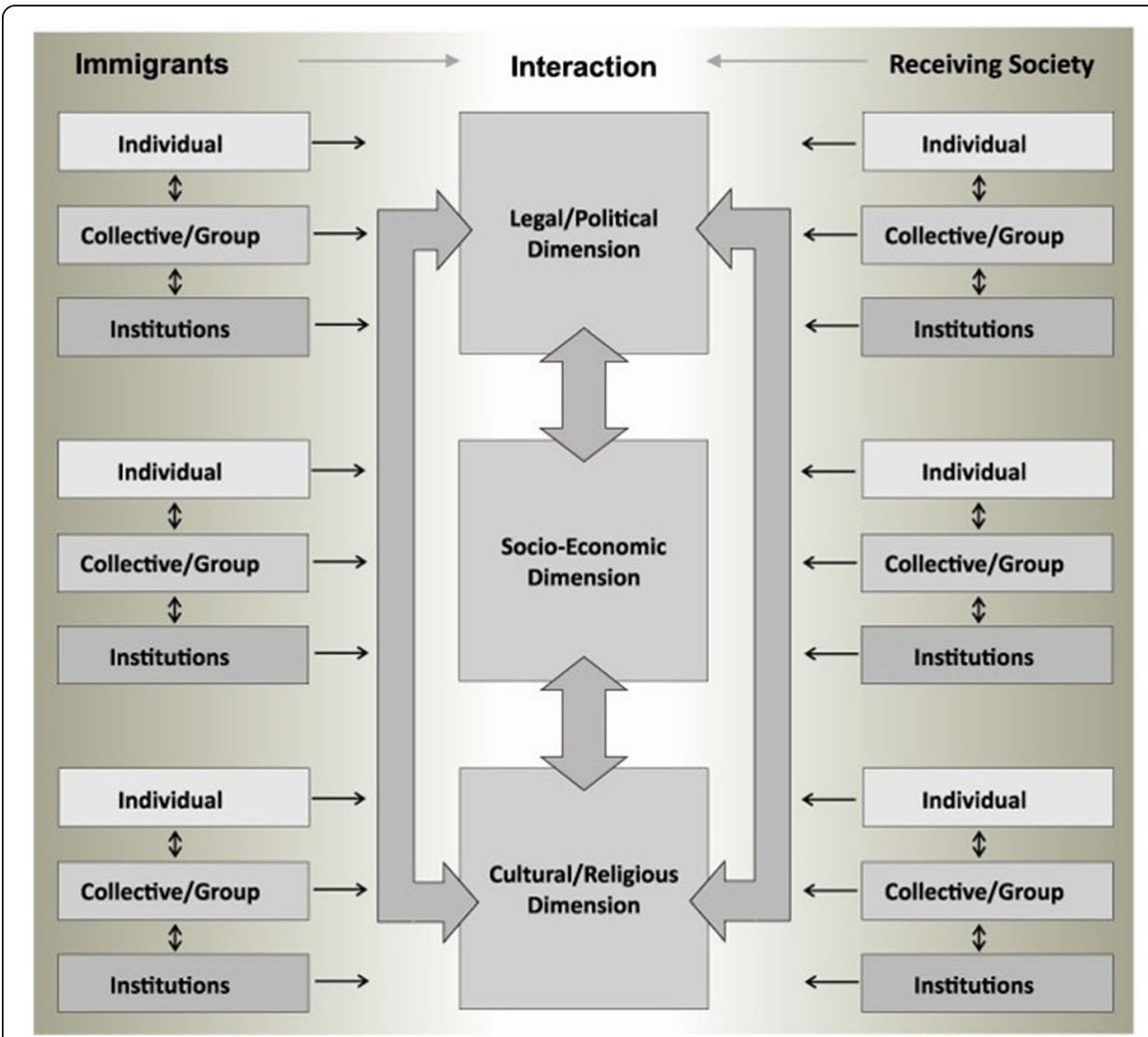

Fig. 1 A heuristic model for the empirical study of integration processes. Source: Penninx \& Garcés-Mascareñas (2016, p. 16)

\section{The study of integration processes: an alternative to Schinkel}

The term integration refers to the process of settlement of newcomers in a given society, to the interaction of these newcomers with the host society, and to the social change that follows immigration. From the moment immigrants arrive in a host society, they must secure a place for themselves. Literally, they must find a home, a job and income, schools for their children, and access to health facilities. They must find a place in a social and cultural sense as well, as they have to establish cooperation and interaction with other individuals and groups in society. They also have to get to know and use institutions of the host society, and the latter have to recognize and accept immigrants as political, economic and cultural actors. All of these elements are assumed to work as a two-way process, in which migrants adapt and change, but also the host society does not remain unaffected. It is the interaction between the two, the immigrants (the left part in Fig. 1) and the receiving society, with its characteristics and reactions to the newcomers (the right part of Fig. 1) that determines the direction and the temporal outcomes of the integration process. However, these two 'partners' are unequal in terms of power and resources. The receiving society, especially its institutional structure and reaction to newcomers, is far more decisive for the outcome of the process than the immigrants themselves are.

All of the elements above and more, are part of our definition of integration as 'the process of becoming an accepted part of society'. This elementary definition is intentionally open in two regards. First, it emphasizes the process character of 
integration rather than defining an end situation. Second, in contrast to the normative models developed by political theorists, it does not specify beforehand the degree of or even the particular requirements for acceptance by the receiving society. This makes the definition highly useful for empirical study of these processes. Measuring the degree of becoming an accepted part of society (or not) will allow us to capture the diversity of (stages of) the process. We do need to specify within this basic definition what should be measured; that is, what are the indicators of integration and where might we find them.

The basic definition of integration encompasses three analytically distinct dimensions in which people may (or may not) become accepted parts of society: (i) the legal-political, (ii) the socio-economic, and (iii) the cultural-religious dimension.

The legal-political dimension refers to residence and political rights and statuses. The basic question here is whether and to what extent are immigrants regarded as fully-fledged members of the political community. The position of an immigrant or the 'degree of integration' has two extreme poles. One is the position of the irregular immigrant who is not part of the host society in the legal-political sense. The other is the position of the immigrant who is (or has become) a national citizen. In between there is enormous variety, which has increased in recent decades in Europe as a consequence of attempts of states to 'regulate' international migration and the new statuses and rights stemming from the EU migration regime (among others, EU nationals versus third-country nationals).

The socio-economic dimension refers to the social and economic position of residents, irrespective of their national citizenship. Within this dimension, the position of immigrants can be analysed by looking at their access to and participation in domains that are crucial for any resident. Do immigrants have equal access to institutional facilities for finding work, housing, education, and health care? Do they use these facilities? What is the outcome of immigrants' participation compared to that of natives with comparable qualifications? Since needs and aspirations in these domains are relatively universal (basic needs are largely independent of cultural factors), access to and participation of immigrants and natives in these areas can be measured comparatively. The outcomes, particularly when they are unequal, provide useful inputs for policies.

The cultural-religious dimension pertains to the domain of perceptions and practices of immigrants and the receiving society as well as their reciprocal reactions to difference and diversity. If newcomers see themselves as different and are perceived by the receiving society as culturally or religiously different, they may aspire to acquire a recognized place in these respects. For their part, the receiving society may or may not accept cultural or religious diversity. Here again we find two extremes. At one extreme, new diversity may be rejected and immigrants required to adapt and assimilate into mono-cultural and mono-religious societies. At the other extreme, ethnic identities, cultures, and world views may be accepted on an equal level in pluralistic societal systems. Between these two extremes again are many in-between positions, such as accepting certain forms of diversity in the private realm but not, or only partly, in the public realm.

This third dimension, and the specific positions of immigrants and immigrant groups, is more difficult to measure, basically for two reasons. Firstly, it is less about objective differences and (ethnic, cultural, and religious) diversity than about perceptions and 
reciprocal normative evaluations of what is defined as different and the consequences of such categorizations. Categorizations may become stereotypes, prejudices, and ultimately part of immutable racist ideologies. Moreover, the basis of categorizations may change. In the guest worker period (1955-1975), for example, the fact that an increasing share of immigrant workers implied Muslims was not seen as relevant; they were primarily temporary workers. It was only from the 1990s on that such migrants and their families were categorized as coming from Muslim countries and were primarily seen as Muslims. Secondly, categorizations and reciprocal perceptions manifest themselves differently at different levels (i.e., at the individual, collective, and institutional levels), and the consequences may also differ. If contacts between individuals are coloured by prejudice, interactions may be uncomfortable but may have a limited societal impact. Yet, at the institutional level, if employers base their recruitment of workers on stereotyped or prejudiced perceptions and procedures, the negative consequences for individual immigrants may be substantial, as may be the broader societal impact.

It is important to realize that these three dimensions are not fully independent of one another. The legal-political dimension may condition the socio-economic and the cultural-religious dimensions (represented by arrows in Fig. 1). From the perspective of individual immigrants, factors such as illegal residence, extended uncertainty about future residence rights and lack of access to local and national political systems and decision-making processes have negative implications for opportunities and participation in the socioeconomic and political realms. From the perspective of the receiving society, exclusionary policies are an expression of a general perception of immigrants as outsiders, which inevitably adversely affects immigrants' integration. The cultural-religious dimension (represented by another arrow in Fig. 1) may similarly impact the socioeconomic dimension. For example, negative perceptions of certain immigrants may lead to prejudice and discrimination by individuals, organizations, or institutions in the receiving society, and this may reduce immigrants' opportunities even if access is legally guaranteed - in domains such as housing, education, health care, and the labour market.

Processes of immigrants' integration take place and can be measured at different levels. The first level is that of individuals, both migrants and natives of the receiving society. For the first dimension, immigrants' integration at the individual level can be measured in terms of their legal status and political participation. For the second dimension, we can look at their socio-economic integration and position in the 'hard' domains of housing, work, education, and health. For the third dimension, we would measure their identification with a specific cultural-religious group and with the receiving society, as well as their cultural and religious practices and how these are valued. In our conceptual definition of integration, we should measure as much the perceptions, attitudes and behaviour (or acceptance) of native individuals towards newcomers and the consequences of these.

The second level is that of organizations. There are the organizations of immigrants, which mobilize resources and ambitions of the group. These organizations may be strong or weak; they may orient themselves primarily towards (certain aspects of participation in) the receiving society or to specific cultural and religious needs of the group. They may become an accepted part of civil society - and a potential partner for integration policies - or isolate themselves or be excluded by the host society. There 
are also organizations of the receiving society. Their extent of openness to newcomers, their perceptions of and behaviour towards individual immigrants and their organizations might be of crucial importance for immigrants' integration. Research has shown, for example, that in the absence of a governmental integration policy in Germany until 2002, NGOs, particularly trade unions and churches, played a crucial role in the integration processes of guest workers and their families (Marino, Roosblad, \& Penninx, 2017; Penninx \& Roosblad, 2000). The third level is that of institutions, understood as standardized, structured, and common ways of acting in a socio-cultural setting. Two kinds of institutions are of particular relevance. The first are the general public institutions of the receiving society in the three dimensions: institutional arrangements of the political system; institutional arrangements in the labour market, housing, education, and public health; and institutional arrangements for cultural and religious diversity. Laws, regulations, and executive organizations, but also unwritten rules and practices, are part of these institutions. Though general institutions are supposed to serve all citizens in an equal manner, they may impede access or equitable outcomes for immigrants. They may exclude immigrants formally, either completely - as does the political system of most countries or partially - as when social security and welfare systems offer only limited services to non-citizens. Yet, even if access for all residents is guaranteed by law, institutions may hamper access or equitable outcomes by virtue of their historically and culturally-determined ways of operating, for instance by failing to take into account immigrants' history, their cultural and religious backgrounds, or their language abilities. Thus, adequate functioning of general public institutions - and their potential to adapt to growing diversity - is of paramount importance. At this level, integration and exclusion are 'mirror concepts' (see Penninx, 2001).

The second type are institutions specifically 'of and for' immigrant groups, such as certain religious or cultural ones. Unlike general institutions, the value and validity of any group-specific institution is confined to those who voluntarily choose and adhere to them. Although their place is primarily in the private sphere, group-specific institutions may also manifest themselves in the public realm as civil society actors, as the history of churches, trade unions, cultural, leisure, and professional institutions in European cities and states shows. Some migrant-specific institutions may become accepted parts of society, equivalent to institutions of native groups. Others, however, might either isolate themselves or remain unrecognized or even excluded.

Different mechanisms operate at the individual, organizational, and institutional levels, but the outcomes at all of these levels are clearly interrelated. Institutional arrangements largely determine organizations' opportunities and scope for action, and they may exert significant influence on how immigrant organizations develop and orient themselves. Institutions and organizations, in turn, together create the structure of opportunities and limitations for individuals. Conversely, individuals may mobilize to change the landscape of organizations and may even contribute to significant changes in general institutional arrangements. In view of the uneven distribution of power and resources noted above, such examples are scarce but they are not non-existent.

The analytical concept of the process of integration can indeed also be used to evaluate research efforts, identify research gaps and see imbalances. One sees 
immediately that "integration measurement" is lopsidedly strong on the individual level of immigrants in the socioeconomic and cultural-religious dimension, leaving out the interaction with three levels at the side of the society. Also research that Schinkel mentions at the end of his essay as "moving beyond integration research" has a clear place in this model (mostly at the right side in the legal/political and cultural-religious dimension.

\section{Conclusion}

A number of Schinkel's critical observations on the concept of immigrant integration and its use in Europe, specifically in the Netherlands, are right. There is a lot of fuzziness around the concept of integration (as there is an any other term for processes of (non-)settlement that follow arrival in a new society). Integration (and other terms) are often used selectively and in a normative sense in political rhetoric and also in research. Research and policy are often also connected and interwoven, so that it not clear how politics and policy influences research and vice versa. Where do these problems come from and are there solutions?

Schinkel's diagnosis of why these shortcomings exist and whose shortcomings these are, is erratic. Firstly, he does not recognize that the concept of integration has fundamental different functions in research and in policy. He ascribes the (ab) use of concepts (of multiculturalism and integration) in politics and policymaking to research. That makes his diagnosis of why research is problematic in its conceptualization and operationalization misleading. Secondly, Schinkel's analysis focuses on the assumed function of research: "..it plays a crucial role in the problematization of migrant others" and 'it is part of the contingent way in which 'immigrant integration' sustains a classed and raced form of dominance that is less precisely called 'native' or even 'nativist' than 'white'." Such sweeping interpretations discard both the possibility of research being sound and independent, and the possibility of research to (potentially) contribute to sound policies. That leads Schinkel to plea "for a social science against immigrant integration policy", whatever that would mean.

In the second part of this contribution I propose that we - researchers - do have a possibility to do better than to do research "against integration policy". I would even say that we have the duty to do better. The alternative solution to problems of research that Schinkel signalizes has the following three building blocks. The first is that research use a broad, heuristic, scientific definition of the process of integration as an analytical concept to study the (outcomes of) interaction between newcomers and the receiving society at three levels (individual, collective and institutional), taking into account three dimensions of that process: the juridical/legal, the socioeconomic and the cultural/religious dimension. Such a definition is (and should be) non-normative and independent of any policy concept of integration.

The second is that researchers study integration policies as fundamentally different from the analysis of the process of integration. Policies should be studied as - by definition normative, politics driven - efforts to steer integration processes. Key questions refer to the framing of the problem that reflects perceived causes and remedies for it.

The third element of the alternative solution is in practice probably the most difficult: researchers should be aware of the consequences of policy-research-relations. Safeguarding scientific independence against mounting pressures on programming and 
content of research - often through funding of research - is indeed a hard task, particularly in situations of strong politicization of the topics of migration and integration.

\section{Endnotes}

${ }^{1}$ Schinkel mentions Alba and Foner by name. Schinkel's apologies for this racist mentioning would be in place. You may disagree and argue with them on scientific grounds, but not because they are "privileged whites".

\section{Authors' contributions}

I, RP, am the sole author of this contribution. I have read and approved the proofs.

\section{Competing interests}

The author declares that he has no competing interests.

\section{Publisher's Note}

Springer Nature remains neutral with regard to jurisdictional claims in published maps and institutional affiliations.

Received: 30 August 2018 Accepted: 18 October 2018

Published online: 16 April 2019

\section{References}

Bommes, M. (2012). Transnationalism or assimilation? In C. Boswell, \& G. D'Amato (Eds.), Immigration and social systems: Collected essays of Michael Bommes, (pp. 107-124). Amsterdam: Amsterdam University Press IMISCOE Research. Retrieved from https://www.imiscoe.org/docman-books/257-boswell-a-damato-eds/file.

Boswell, C. (2009). The political uses of expert knowledge: Immigration policy and social research. Cambridge: Cambridge University press.

Entzinger, H. B. (1986). Vergelijkend beleidsonderzoek op het terrein van etnische minderheden [Comparative policy research on ethnic minorities]. Mens en Maatschappij, 60(1).

Entzinger, H. B. (1984). Het minderhedenbeleid; dilemma's voor de overheid in Nederland en zes andere immigratielanden in Europa [Minorities' policy: dilemmas for the government of the Netherlands and six other immigration countries in Europe]. Netherlands: Meppel/Amsterdam, Boom.

Esser, H. (1980). Aspekte der wanderungssoziologie: Assimilation und integration von wanderern, etnische gruppen und minderheiten, eine handlungstheoretische analyse [Aspects of the migration sociology: assimilation and integration of migrants, ethnic groups and minorities, an action theoretic analysis]. Darmstadt: Luchterhand.

Esser, H. (2004). Welche Alternativen zur "Assimilation" gibt es eigentlich? [What alternatives are there for Assimilation?]. IMIS - Beiträge, 23, 41-59. Osnabrück.

Favell, A. (2003). Integration/assimilation. In M. Gibney, \& R. Hansen (Eds.), Immigration and asylum: From 1900 to the present. Santa Barbara: ABC-Clio Database on-line. Retrieved from www.sscnet.ucla.edu/soc/faculty/favell/Clio.htm.

Hammar, T. (Ed.) (1985). European immigration policy. A comparative study. Cambridge: Cambridge University Press.

Heckmann, F. (1981). Die Bundesrepublik: Ein Einwanderungsland? Zur Soziologie der Gastarbeiterbevölkerung als Einwandererminorität [The Federal Republic of Germany: an immigration country? Towards a sociology of the guest worker population as an immigrant minority]. Stuttgart: Klett-Cotta.

Heckmann, F. (2006). Integration and integration policies. IMISCOE Network Feasibility Study. Retrieved from www.efms.unibamberg.de/pdf/INTPOL\%20Final\%20Paper.pdf.

Heckmann, F. (2015). Integration von Migranten: Einwanderung und neue Nationbildung [Integration of migrants: immigration and new nation-building]. Wiesbaden: Springer.

Heckmann, F., \& Schnapper, D. (2003). The integration of immigrants in European societies. Stuttgart: Lucius and Lucius.

Hoffmann-Nowotny, H.-J. (1973). Soziologie des Fremdarbeiterproblems: eine theoretische und empirische Analyse am Beispiel der Schweiz [Sociology of the foreign workers' issue: a theoretical and empirical analysis of the Swiss case]. Stuttgart: Ferdinand Enke.

Kymlicka, W. (2001). Politics in the vernacular: Nationalism, multiculturalism, citizenship. Oxford: OUP.

Marino, S., Roosblad, J., \& Penninx, R. (Eds.) (2017). Trade unions and migrant workers: New contexts and challenges in Europe. Cheltenham/ Northhampton: Edward Elgar Publishing.

Penninx, R. (1988). Minderheidsvorming en emancipatie. Balans van kennisverwerving ten aanzien van immigranten en woonwagenbewoners 1967-1987, (p. 290) [Minority formation and emancipation: state-of-the-art of research on immigrants and caravan dwellers 1967-1987, (p. 290). Alphen aan den Rijn: Samsom (Doctoral dissertation). Universiteit van Amsterdam.

Penninx, R. (2001). Immigrants and the dynamics of social exclusion. Lessons for anti-discrimination policies. In F. Lindo, \& M. van Niekerk (Eds.), Dedication and detachment. Essays in honour of Hans Vermeulen, 193-211. Amsterdam: Het Spinhuis.

Penninx, R. (2005). Integration of migrants: Economic, social, cultural and political dimensions. In M. Macura, A. L. MacDonald, \& W. Haug (Eds.), The new demographic regime: Population challenges and policy responses, (pp. 137-152). New York, Geneva: United Nations.

Penninx, R. (2017). Research-policy dialogues in migration and integration at the EU-level: Who tells whom what to do? In S. Carrera, A. Geddes, E. Guild, \& M. Stefan (Eds.), Pathways towards legal migration into the EU: Reappraising concepts, trajectories and policies, (pp. 164-175). Brussels: CEPS Retrieved from https://www.ceps.eu/publications/pathways-towardslegal-migration-eu-reappraising-concepts-trajectories-and-policies. 
Penninx R. \& Garcés-Mascareñas B. (2016) The Concept of Integration as an Analytical Tool and as a Policy Concept. In: B. Garcés-Mascareñas, \& R. Penninx (Eds.), Integration Processes and Policies in Europe, (pp. 11-29). IMISCOE Research Series. Springer, Cham

Penninx, R., \& Roosblad, J. (Eds.) (2000). Trade unions, immigration, and immigrants in Europe, 1960-1993. A comparative study of the attitudes and actions of trade unions in seven West European countries. New York/Oxford: Berghahn Books.

Scholten, P., Entzinger, H., Penninx, R., \& Verbeek, S. (Eds.) (2015). Integrating immigrants in Europe: Research-policy dialogues. Dordrecht: Springer Open.

Scholten, P. W. A. (2011). Framing immigrant integration: Dutch research-policy dialogues in comparative perspective. Amsterdam: Amsterdam University Press.

Van Amersfoort, H. (1982). Immigration and the formation of minority groups: The Dutch experience, 1945-1973. Cambridge: Cambridge University Press.

Van Amersfoort, J. M. M. (1983). Migratie-onderzoek, overheidsfinanciering en beleid: aantekeningen van een participant [Research on migration, governmental funding and policy: notes from a participant]. Grafiet, 4, 130154.

Verbeek, S., Entzinger, H., \& Scholten, P. (2015). Research-policy dialogues in the Netherlands. In P. Scholten, H. Entzinger, R. Penninx, \& S. Verbeek (Eds.), Integrating immigrants in Europe: Research-policy dialogues, (pp. 213-232). Dordrecht: Springer Open.

Submit your manuscript to a SpringerOpen ${ }^{\odot}$ journal and benefit from:

- Convenient online submission

- Rigorous peer review

- Open access: articles freely available online

High visibility within the field

- Retaining the copyright to your article

Submit your next manuscript at $\boldsymbol{\nabla}$ springeropen.com 